TONINATO, BO; SOUZA, DHG; PONTALTI, PR; LOPES, APM; DIAS-ARIEIRA, CR. 2019. Meloidogyne javanica control in lettuce with fertilizers applied isolated or associated with biological product. Horticultura Brasileira 37: 384-389. DOI - http://dx.doi.org/10.1590/S0102-053620190404

\title{
Meloidogyne javanica control in lettuce with fertilizers applied isolated or associated with biological product
}

\author{
Bruna O Toninato ${ }^{1 \mathbb{D}}$; Dablieny HG Souza ${ }^{2 \mathbb{D}}$; Paulo R Pontalti ${ }^{1 \mathbb{D}}$; Ana PM Lopes ${ }^{1 \mathbb{D}}$; Claudia R Dias- \\ Arieira ${ }^{1} \mathbb{D}$
}

${ }^{1}$ Universidade Estadual de Maringá(UEM),Umuarama-PR, Brasil; brunaorlandini@gmail.com; paulopontalti@hotmail.com; anna_apml@ hotmail.com; crdarieira@uem.br (correspondent author). ${ }^{2}$ Universidade Estadual do Oeste do Paraná, (UNIOESTE) Marechal Cândido Rondon-PR, Brasil; dabligarcia@hotmail.com

\begin{abstract}
Root-knot nematodes limit lettuce crop productivity. Efficient control is achieved through integrated management, and research about the efficiency of new products for nutrition and biological control is required. Thus, the objective of this study was to evaluate the effect of fertilizers, applied alone or in combination with microorganisms based product on the control of Meloidogyne javanica in lettuce. In the first research (research 1), conducted at two different periods, the products Agro-Mos ${ }^{\circledR}$, Soil-Set ${ }^{\mathrm{TM}}$ and CopperCrop $^{\circledR}$ applied on shoots were evaluated; in research 2, the same products were applied isolated on shoots or associated to NemOut ${ }^{\mathrm{TM}}$ (Bacillus licheniformis, B. subtilis and Trichoderma longibrachiatum) applied to the soil. In research 1, the fertilizers Agro-Mos ${ }^{\circledR}$, Soil-Set ${ }^{\mathrm{TM}}$ and Copper-Crop ${ }^{\circledR}$ applied alone promoted reduction in reproduction of $M$. javanica ranging from 31 to $75 \%, 36$ to $79 \%$, and 71 to $75 \%$, respectively. The effect on plant development was variable, obtaining better results of fresh shoot mass applying Copper-Crop ${ }^{\circledR}$. The combination of products did not have an additional effect on the control of the nematode, on the contrary, in general the products had antagonistic action. However, fertilizers and biological control applied isolated were efficient for nematode control.
\end{abstract}

Keywords: Lactuca sativa, alternative control, root-knot nematode, integrated management.

\section{RESUMO}

Controle de Meloidogyne javanica em alface com fertilizantes isolados ou associados a produto biológico

Os nematoides das galhas limitam a produtividade da cultura da alface e o controle eficiente dá-se por meio do manejo integrado, sendo necessárias pesquisas em relação à eficiência de novos produtos para nutrição e controle biológico. Assim, objetivou-se avaliar o efeito de fertilizantes, aplicados isoladamente, ou em associação com produto à base de microrganismos, no controle de Meloidogyne javanica em alface. No primeiro experimento (Experimento 1), conduzido em duas épocas distintas, foram avaliados os produtos Agro-Mos $^{\circledR}$, Soil-Set ${ }^{\mathrm{TM}}$ e Copper-Crop ${ }^{\circledR}$ aplicados em parte aérea; no Experimento 2, os mesmos produtos foram aplicados em parte aérea isoladamente ou associados ao NemOut ${ }^{\mathrm{TM}}$ (Bacillus licheniformis, B. subtilis e Trichoderma longibrachiatum) aplicado ao solo. No Experimento 1, os fertilizantes Agro-Mos ${ }^{\circledR}$, Soil-Set ${ }^{\mathrm{TM}}$ e Copper-Crop ${ }^{\circledR}$, aplicados isoladamente, promoveram reduções na reprodução de $M$. javanica que variaram de 31 a $75 \%, 36$ a $79 \%$ e 71 a $75 \%$, respectivamente. O efeito sobre o desenvolvimento vegetal foi variável, sendo obtidos melhores resultados de massa fresca de parte aérea quando se aplicou o Copper-Crop ${ }^{\circledR}$. A associação entre produtos não promoveu efeito adicional no controle do nematoide, ao contrário, em geral, os produtos tiveram ação antagônica. No entanto, os fertilizantes e o controle biológico aplicados isoladamente foram eficientes para o controle do nematoide.

Palavras-chave: Lactuca sativa, controle alternativo, nematoide das galhas, manejo integrado.

Received on January 18, 2019; accepted on October 1, 2019

$\mathrm{L}$ ettuce (Lactuca sativa) is one of the most economically important vegetables in the world, being widely consumed in Brazil (Sediyama et al., 2016). Its productivity may be limited by different diseases, such as those caused by phytonematodes. The species Meloidogyne incognita and M. javanica stand out among the most important for the culture (Pinheiro, 2017).

After this parasite has penetrated the roots of the host, it induces the feeding site, characterized by cellular hypertrophy and hyperplasy, which affects the absorption of water and nutrients and reflects on the appearance of characteristic symptoms in the roots, called galls. Infected lettuce shoots become yellowish, rickety, smaller, lighter and can wilt in the hottest periods of the day (Gheysen \& Fenoll, 2002).

The control of nematodes is complex, since most cultivars available on the market are susceptible to Meloidogyne spp. (Dias-Arieira et al., 2012). In addition, the use of chemical control has not been recommended, since the 
products available on the market are highly toxic and there are no specific chemicals registered for the lettuce crop in Brazil.

Crop rotation with non-host plants or antagonist is one of the most suitable methods for nematode control in vegetables (Pinheiro, 2017). However, it has limitations due to the wide host range of the root-knot nematodes and the resistance of the producer, who should keep the planting area without commercial production for a certain period.

Regarding control of nematodes, research for alternative practices that may help in reducing the population or improving the productivity of the plant even in the presence of nematodes is constant. In this context, products intended for plant nutrition may be a viable alternative since it is known that fertilizer use can directly affect nematodes, interfering with their life cycle (Couto et al., 2016; Rumiani et al., 2016), or indirectly, altering the resistance of the plant to them (Costa et al., 2010; Junqueira et al., 2011; Gomes et al., 2016; Miamoto et al., 2017).

Biological control is another alternative that has been emphasized. It consists on the application of microorganisms that have some direct or indirect effect on the nematodes. The activity of the rhizobacteria of the genus Bacillus spp., as well as the fungi of the genus Trichoderma, has been investigated, mainly for the control of the root-knot nematode (Sharon et al., 2011; Yu et al., 2015; Zheng et al., 2016; Hu et al., 2017). However, several products marketed as soil conditioners based on these organisms have not yet been investigated about the effect on nematodes.

Considering the information previously discussed, this study aimed to evaluate the efficiency of nutrients and microorganisms based products to control M. javanica in lettuce.

\section{MATERIAL AND METHODS}

\section{Search 1 - Fertilizer applied to shoot in control of Meloidogyne javanica}

The research was carried out in a greenhouse at Universidade Estadual de Maringá, in Umuarama-PR $\left(23^{\circ} 47^{\prime} 28^{\prime \prime} \mathrm{S}, 53^{\circ} 15^{\prime} 23^{\prime \prime} \mathrm{W}, 430 \mathrm{~m}\right.$ altitude), in completely randomized design with four treatments and five replicates. The research was conducted in two different periods, the first between April and August, 2015 (called Research 1, Trial 1), under mean minimum and maximum temperatures 16.8 and $26.3^{\circ} \mathrm{C}$, respectively. And the second one between November 2015 and March 2016 (called Research 1, Trial 2), whose temperatures were 21.1 and $30.3^{\circ} \mathrm{C}$, respectively.

Tomato seedlings (Solanum lycopersicum), cultivar San Marzano, were produced in 128-cell polystyrene trays, containing Bioplant ${ }^{\mathbb{}}{ }^{\mathrm{P}}$ commercial substrate and, 25 days after germination, were transplanted to pots containing 2 liters of a soil:sand mixture (2:1), previously autoclaved $\left(120^{\circ} \mathrm{C} / 2\right.$ hours $)$. Ten days before transplantation, 1.14 g lime and $2.80 \mathrm{~g}$ NPK (20-20-20) were applied to the soil. Two days after transplantation, the seedlings were inoculated with a suspension of $4 \mathrm{~mL}$ containing 2,000 eggs and eventual second stage juveniles (J2) of $M$. javanica, in four open perfurations in the soil around the seedling. The inoculum was obtained from a pure population of the nematode, maintained in roots of tomato cv. Santa Clara and previously extracted according to the methodology proposed by Hussey \& Barker, adapted by Boneti \& Ferraz (1981). This part of the research had the objective of simulating a naturally infested soil in which the nematode is found in egg masses or in residual roots.

Forty days after inoculation, the shoots of the plants contained in the pots were cut and discarded and the soil was slightly revolved. Then, one lettuce seedling, cv. Vanda, approximately 20 days after germination, was transplanted to these pots. On the day of transplantation, seedlings were treated with the products Agro-Mos ${ }^{\circledR}[2.75 \%$ sulfur (46.12 $\left.\mathrm{g} \mathrm{L}^{-1}\right) ; 2.00 \%$ copper (24.60 $\left.\mathrm{g} \mathrm{L}^{-1}\right) ; 2.00 \%$ zinc $\left(24.60 \mathrm{~g} \mathrm{~L}^{-1}\right)$; $1.23 \mathrm{~g} \mathrm{~cm}^{-3}$ density; $\mathrm{pH} 2.84$ ] at the dose $150 \mathrm{~mL} / 100 \mathrm{~L}$ water; Soil-Set ${ }^{\mathrm{TM}}[3.75 \%$ sulfur (33.83 $\left.\mathrm{g} \mathrm{L}^{-1}\right) ; 3.00 \%$ copper (36.90 $\left.\mathrm{g} \mathrm{L}^{-1}\right) ; 1.60 \%$ iron $\left(19.68 \mathrm{~g} \mathrm{~L}^{-1}\right)$; manganese $0.80\left(9.84 \mathrm{~g} \mathrm{~L}^{-1}\right) ; 3.20 \%$ zinc
(39.36 $\left.\mathrm{g} \mathrm{L}^{-1}\right) ; 2.13 \%$ organic carbon; $1.23 \mathrm{~g} \mathrm{~cm}^{-1}$ density; $\mathrm{pH} 2.55$ ] at the dose $150 \mathrm{~mL} / 100 \mathrm{~L}$ water; or Copper-Crop ${ }^{\circledR}$ [4.09\% nitrogen $\left(54.81 \mathrm{~g} \mathrm{~L}^{-1}\right) ; 10.0 \%$ copper (134.0 $\left.\mathrm{g} \mathrm{L}^{-1}\right) ; 3.53 \%$ organic carbon; $1.34 \mathrm{~g} \mathrm{~cm}^{-1}$ density; $\mathrm{pH} 1.34$ ] at the dose $35 \mathrm{~mL} / 100 \mathrm{~L}$ water. Plants treated with water were used as control treatment. All products were applied, spraying the leaf surface until runoff, protecting the soil with plastic film to avoid contact. The products were applied at the doses recommended by the manufacturer Improcrop ${ }^{\circledR}$ do Brasil Ltda.

Lettuce plants were irrigated daily and kept in a greenhouse until 45 days after transplantation. Subsequently, plants were collected, separating shoots and roots. Roots were carefully washed, placed on absorbent paper to remove excess water and fresh mass was determined. Afterwards, nematodes were extracted according to the methodology already mentioned, and the total number of nematodes was evaluated in a Peters chamber under light microscope. This total number of nematodes was divided by the root mass, obtaining the number of nematodes/g of roots. In Research 1, Trial 2, besides the parameters already mentioned, fresh mass and dry mass of shoots were evaluated. Dry mass of shoots was obtained after drying the material in an oven with forced air circulation at $65^{\circ} \mathrm{C}$ during three days.

Data were submitted to analysis of variance at $5 \%$ probability. For nematological parameters, the original data were transformed by $\sqrt{(\mathrm{x}+0.5)}$ to meet the normality assumptions, according to Shapiro Wilk. Then, means were compared by Tukey test at $5 \%$ probability, using the statistical program Sisvar (Ferreira, 2011).

Search 2 - Combination of fertilizers and Nem-Out ${ }^{\mathrm{TM}}$ for control of Meloidogyne javanica

This research was similar to research 1 , however, it was carried out between January and May 2016, whose temperatures were 20.0 and $29.5^{\circ} \mathrm{C}$ respectively, using pots containing $1 \mathrm{~L}$ of autoclaved soil:sand substrate $(2: 1)$. In addition, this research was in a 4 x 2 factorial, with four treatments in 
shoots (water, Agro-Mos ${ }^{\circledR}$, Soil-Set ${ }^{\mathrm{TM}}$ and Copper-Crop ${ }^{\circledR}$ ), with or without Nem-Out ${ }^{\mathrm{TM}}$ [Bacillus licheniformis, $B$. subtilis, Trichoderma longibrachiatum, with total microbiological count of $3.75 \times 10^{8} \mathrm{CFU} \mathrm{g}^{-1}$; protease, silanase, cellulase of which amounts were not stated by the manufacturer] at a dose of $5 \mathrm{~kg} /$ hectare, as recommended by the manufacturer (Improcrop ${ }^{\circledR}$ do Brasil Ltda.), applied to the planting furrow at the time of transplantation. Fifty-six plants were evaluated, one per experimental unit.

In this research, the same parameters described in Research 1, Trial 1 were evaluated. Statistical analysis was performed as already reported in research 1, however, products applied to shoots were compared by Tukey test and the application of Nem-Out ${ }^{\mathrm{TM}}$ by the Bonferroni $\mathrm{T}$ test, both at $5 \%$ probability.

\section{RESULTS AND DISCUSSION}

\section{Research 1 - Fertilizers applied to shoots for the control of Meloidogyne javanica}

There was no statistical difference in Trial 1 for the variable root mass (Table 1). In Trial 2, Agro-Mos ${ }^{\circledR}$ and Soil-Set ${ }^{\mathrm{TM}}$ promoted an increase in root mass compared to the control. Agro-Mos ${ }^{\circledR}$ presented the highest mean for this parameter $(11.47 \mathrm{~g})$, followed by Soil-Set ${ }^{\mathrm{TM}}$ treatment $(8.52$ g) (Table 1). Several factors possibly influenced the difference between these results, being the most probable the temperature, whose minimum and maximum averages in trial 1 were $16.8^{\circ} \mathrm{C}$ and $26.3^{\circ} \mathrm{C}$, while in trial 2 were 21.1 and $30.3^{\circ} \mathrm{C}$, respectively.

All treatments reduced the total number of $M$. javanica in both trials and the number of nematodes per gram of root in Trial 2. However, in trial 1, only the treatment Copper-Crop ${ }^{\circledR}$ differed from the control for the number of nematodes/g of roots (Table 1), which may be due to differences in plant root system development. The treatment with Agro-Mos ${ }^{\circledR}$ promoted 31 and $75 \%$ reductions in the total nematode population in trials 1 and 2 , respectively.
Despite the shortage of studies aiming the control of nematodes with Agro-Mos ${ }^{\circledR}$, this product controlled $M$. javanica in soybean when applied alone on shoots (Miamoto et al., 2017), contributing not only to the control of the pathogen, but also to the development of the crop. In addition, recent studies revealed that Agro-Mos ${ }^{\circledR}$ decreases the number of third and fourth stage juveniles (J3 and $\mathrm{J} 4$ ) of $M$. javanica within tomato roots, although it did not interfere with the number of $\mathrm{J} 2$ that penetrated the roots (Chidichima et al., 2018), which may be an indication that the product delays the development of the nematode in treated plants. Agro-Mos ${ }^{\circledR}$ has phosphorylated mannanoligosaccharide from the cell wall of Saccharomyces cerevisiae as active ingredient, considered an inducer of resistance in plants (Junqueira et al., 2011).

In addition to nematode control, the efficiency of Agro-Mos ${ }^{\circledR}$ in the control of other pathogens has been studied and the results have been positive in the management of fungal diseases of shoot, including anthracnose in guava and leaf diseases in strawberry (Gouvea et al., 2009; Gomes et al., 2016). The application of Agro-Mos ${ }^{\circledR}$ resulted in increased activity of chitinase and glucanase proteins, which have the capacity to hydrolyze fungal cells (Gouvea et al., 2009). The product also

Table 1. Fresh root mass, total nematode, percentage of total nematode, reduction in relation to the control, and nematode per gram of lettuce root, inoculated with 2000 nematodes and submitted to different shoot treatments. Umuarama, UEM, 2018.

\begin{tabular}{|c|c|c|c|c|}
\hline \multirow{2}{*}{ Treatment } & $\begin{array}{c}\text { Root mass } \\
(\mathrm{g})\end{array}$ & $\begin{array}{c}\text { Total } \\
\text { nematode }^{y}\end{array}$ & $\begin{array}{c}\text { Reduction total } \\
\text { nematode }(\%)\end{array}$ & $\begin{array}{c}\text { Nematode/g } \\
\text { of roots }^{y}\end{array}$ \\
\hline & \multicolumn{4}{|c|}{ Research 1, trial 1} \\
\hline Control & $1.32^{\mathrm{ns}}$ & $9576 \mathrm{a}$ & - & $7210 \mathrm{a}$ \\
\hline Agro-Mos ${ }^{\circledR}$ & 1.31 & $6632 \mathrm{~b}$ & 31 & $5105 \mathrm{ab}$ \\
\hline Soil-Set ${ }^{\mathrm{TM}}$ & 1.19 & $6096 \mathrm{~b}$ & 36 & $4853 \mathrm{ab}$ \\
\hline Copper-Crop $^{\circledR}$ & 1.06 & $2728 \mathrm{c}$ & 72 & $2530 \mathrm{~b}$ \\
\hline \multirow[t]{2}{*}{ CV $(\%)$} & 17.48 & 32.04 & - & 24.47 \\
\hline & \multicolumn{4}{|c|}{ Research 1, trial 2} \\
\hline Control & $5.75 \mathrm{c}$ & $18860 \mathrm{a}$ & - & $3137 \mathrm{a}$ \\
\hline Agro-Mos ${ }^{\circledR}$ & $11.47 \mathrm{a}$ & $4688 \mathrm{~b}$ & 75 & $369 \mathrm{~b}$ \\
\hline Soil-Set ${ }^{\mathrm{TM}}$ & $8.52 \mathrm{~b}$ & $3952 \mathrm{~b}$ & 79 & $423 \mathrm{~b}$ \\
\hline Copper-Crop $^{\circledR}$ & $7.93 \mathrm{bc}$ & $2893 \mathrm{~b}$ & 85 & $441 \mathrm{~b}$ \\
\hline $\mathrm{CV}(\%)$ & 28.35 & 25.34 & - & 22.69 \\
\hline
\end{tabular}

Means followed by same letters in column do not differ from each other by the Tukey test, $5 \%$ probability. $n s=$ not significant. ${ }^{y}$ Original data transformed by $\sqrt{(x+0.5)}$ for statistical analysis. 
Table 2. Lettuce fresh mass and dry mass of shoots, inoculated with 2,000 nematodes and submitted to different treatments in trial 2. Umuarama, UEM, 2018.

\begin{tabular}{lcc}
\hline Treatment & Fresh mass $(\mathbf{g})$ & Dry mass $(\mathbf{g})$ \\
\hline Control & $29.90 \mathrm{c}$ & $1.77 \mathrm{~b}$ \\
Agro-Mos $^{\circledR}$ & $41.02 \mathrm{bc}$ & $3.23 \mathrm{a}$ \\
Soil-Set $^{\mathrm{TM}}$ & $60.29 \mathrm{ab}$ & $3.10 \mathrm{a}$ \\
Copper-Crop $^{\circledR}$ & $74.55 \mathrm{a}$ & $3.82 \mathrm{a}$ \\
\hline CV $(\%)$ & 26.55 & 21.74 \\
\hline
\end{tabular}

Means followed by same letters in column do not differ from each other by Tukey test, $5 \%$ probability.

Table 3. Fresh root mass, total nematode and nematode per gram of lettuce root inoculated with 2,000 eggs + juveniles of M. javanica and submitted to different shoot treatments, without or with $\mathrm{Nem}-\mathrm{Out}^{\mathrm{TM}}$ in the soil, under two experimental conditions. Umuarama, UEM, 2018.

\begin{tabular}{|c|c|c|c|c|c|}
\hline \multirow[t]{2}{*}{ Treatment } & \multirow{2}{*}{$\begin{array}{l}\text { Average } \\
\text { root mass } \\
\text { (g) }\end{array}$} & \multicolumn{2}{|c|}{$\begin{array}{l}\text { Total nematode } \\
\text { Nem-Out }^{\mathrm{TM}}\end{array}$} & \multicolumn{2}{|c|}{$\begin{array}{c}\text { Nematode/g of roots } \\
\text { Nem-Out }^{\mathrm{TM}}\end{array}$} \\
\hline & & Without & With & Without & With \\
\hline Control & $0.60 \mathrm{a}$ & $5332 \mathrm{aA}$ & $2222 \mathrm{aB}$ & $7841 \mathrm{aA}$ & $4273 \mathrm{aB}$ \\
\hline Agro-Mos $^{\circledR}$ & $0.36 \mathrm{~b}$ & $2180 \mathrm{bA}$ & $1467 \mathrm{aA}$ & $6813 \mathrm{aA}$ & $3761 \mathrm{abB}$ \\
\hline Soil-Set $^{\mathrm{TM}}$ & $0.48 \mathrm{ab}$ & $2880 \mathrm{bA}$ & $1312 \mathrm{aA}$ & $6127 \mathrm{aA}$ & $2678 \mathrm{bB}$ \\
\hline Copper-Crop $^{\circledR}$ & $0.55 \mathrm{a}$ & $2660 \mathrm{bA}$ & $2620 \mathrm{aA}$ & $4586 \mathrm{aA}$ & $5237 \mathrm{aA}$ \\
\hline CV (\%) & 21.87 & \multicolumn{2}{|c|}{31.29} & \multicolumn{2}{|c|}{28.47} \\
\hline
\end{tabular}

Means followed by same lowercase letters in the columns and by same uppercase letters in lines do not differ from each other by Tukey test, $5 \%$ probability. ${ }^{\mathrm{y}}$ Original data transformed by $\sqrt{(\mathrm{x}+0.5)}$ for statistical analysis.

respiration and carbohydrate distribution (Kabata-Pendias, 2011). This element is also cofactor of several enzymes in plant cells, by providing ions and, consequently, influencing cell wall composition and promoting increased synthesis of peroxides, quinones and phenolic compounds, which may induce plant resistance (Marschner, 2012). These attributions can elucidate the obtained results, since the nematodes use mechanical and enzymatic strength to degrade plant cell wall in the penetration process, movement in the cortical parenchyma and feeding. In the case of a more lignified cell wall, such activities will require greater energy expenditure, thus reducing nematode activity and, possibly, the reproduction.

In addition, the presence of Zinc in the product formulation may have contributed to the results, since in the work carried out by Couto et al. (2016), the application of Zinc promoted the reduction of $M$. incognita population in tomato. Besides, Soil-Set ${ }^{\mathrm{TM}}$ was efficient in the preventive control of tomato bacterial spot (Xanthomonas spp.), reducing disease severity when applied to shoots (Rodrigues et al., 2016).

Copper-Crop ${ }^{\circledR}$ was the product that promoted the greatest reduction of $M$. javanica reproduction in lettuce, which was equivalent to 71 and $85 \%$ in trials 1 and 2, respectively (Table 1). The effect of Copper-Crop ${ }^{\circledR}$ for disease management is limited to the protective effect against fungi and shoot bacteria. However, it is known that copper is an element with direct effect on such pathogens, inhibiting their activity at pre-penetration. However, it is not possible to extrapolate this mode of action to nematode control, since there is no direct contact between the product and the parasite. The copper activity in the defense mechanisms activation process discussed earlier can be applied here as well. Furthermore, it has recently been observed that the product reduced the formation of $\mathrm{J} 3$ and $\mathrm{J} 4$ of $M$. javanica in tomato seedlings (Chidichima et al., 2018).

Due to lack of studies, it is difficult to know the mechanisms of action by which these products control nematodes.
Additional studies, involving mainly the expression of resistance enzymes and alteration of root exudates, are necessary to elucidate recurrent questions about the mode of action of fertilizers on nematodes, especially for those applied to shoots.

In trial 2 it was possible to observe that Copper-Crop ${ }^{\circledR}$ and Soil-Set ${ }^{\mathrm{TM}}$ increased fresh mass of shoot (74.55 and $60.29 \mathrm{~g}$, respectively), relative to the control $(29.90 \mathrm{~g})$. All treatments were efficient in increasing shoot dry mass (Table 2). These results were already expected since they are products for plant nutrition. The effect of the different nutrients in the development of plants was elucidated in detail by Marschner (2012).

Research 2 - Combination of fertilizers applied to shoot with NemOut $^{\mathrm{TM}}$ for the control of Meloidogyne javanica

There was no interaction between the factors for fresh root mass. AgroMos $^{\circledR}$ reduced the root system mass when compared to the control and Copper-Crop $^{\circledR}$ (Table 3). Interaction was observed between the factors for both nematological parameters. Nem-Out ${ }^{\mathrm{TM}}$ applied alone reduced nematodes total and nematodes/g of root, which corroborates with results observed in the soybean crop, in which the product was efficient in controlling $M$. javanica and P. brachyurus, when applied alone (Miamoto et al., 2017). In addition, Nem-Out ${ }^{\mathrm{TM}}$ was efficient in the management of Pratylenchus spp. in sugarcane, in researches under controlled conditions (Oliveira et al., 2011). One of the factors that may explain the efficiency of Nem-Out ${ }^{\mathrm{TM}}$ for nematode control is the presence of bacteria of the genus Bacillus, which have been shown to have multiple mechanisms of action, including the production of metabolites toxic to nematodes, competition for nutrients in the rhizosphere, changes in root exudates released by the plant and the ability to induce plant resistance to pathogens (Oliveira et al., 2014; Yu et al., 2015; Zheng et al., 2016; Govindasamy et al., 2017). Moreover, the presence of the fungus Trichoderma longibrachiatum of which the nematicidal effect on $M$. incognita is due to the high capability 
to colonize the rhizosphere, competing with the nematode, and by its direct parasitism (Zhang et al., 2015). In fact, several species and isolates of Trichoderma have shown positive results for the management of plants parasitic nematodes, and their mode of action is attributed to alteration of root exudates, parasitism of eggs and juveniles, stimulus to vegetative development and induction of resistance in plants (Hoyos-Carvajal et al., 2009; Sharon et al., 2011; Zhang et al., 2015).

All products used as foliar fertilizers promoted reduction in the total nematode population, in the absence of Nem-Out ${ }^{\mathrm{TM}}$ (Table 3), corroborating the results of Research 1. On the other hand, in the presence of Nem-Out ${ }^{\mathrm{TM}}$, there was no difference between the treatments with fertilizers and the control. For nematodes per gram of root, the products applied alone did not differ and, in the presence of Nem-Out ${ }^{\mathrm{TM}}$, only Soil-Set ${ }^{\mathrm{TM}}$ showed reduction of $M$. javanica when compared to the control (Table 3). However, the application of Nem-Out ${ }^{\mathrm{TM}}$ reduced nematodes per gram of root in the treatmeants control, Agro-Mos $^{\circledR}$ and Soil-Set ${ }^{\mathrm{TM}}$ (Table 3).

Researches on the evaluation of shoot fertilizers on the control of $M$. javanica are still very scarce, considering that they are registered products with the purpose of supplying the need of nutrients by the plants, and not as pathogen control agents. However, it is known that fertilizers for aerial application can have deleterious effect when in direct contact with microorganisms, including Trichoderma spp. (Dłużniewska, 2008), even though indirect action is poorly studied. On the other hand, there are reports that such products may alter the exudation of substances by the roots, making them more or less attractive to microorganisms (Canarini et al., 2019), since colonization of the rhizosphere depends on the relationship between exudates and microorganisms (Zhang et al., 2014). So, as the fertilizers inhibited the action of the nematode, as presented and discussed in this study, it can be hypothesized that, in some way, they also alter the activity of the bacteria and the fungus that makes up the Nem-Out ${ }^{\mathrm{TM}}$, altering the attractiveness of exudates or causing induction of resistance, in the case of these organisms establish some endophytic relationship. This hypothesis would explain the fact that both products control the nematode when applied alone, but without evident additional effect when associated with each other.

Since studies are conducted under controlled conditions, field research is needed to confirm whether nutrientbased products can be a strategy for composing integrated nematode management.

\section{ACKNOWLEDGEMENTS}

To the PIBIC and PIBITi programs of the UEM-CNPq-FA, for the scholarship granted to the first three authors; to the CNPq for the master's scholarship of the fourth author and for the research productivity scholarship granted to the fifth author.

\section{REFERENCES}

BONETI, JIS; FERRAZ, S. 1981. Modificação do método de Hussey e Barker para extração de ovos de Meloidogyne exigua de raízes de cafeeiro. Fitopatologia Brasileira 6: 553.

CANARINI, A; KAISER, C; MERCHANT, A; RICHTER, A; WANEK, W. 2019. Root exudation of primaty metabolites: mechanisms and their roles in plant responses to environmental stimuli. Frontiers in Plant Science 21: 00157.

CHIDICHIMA, LPS; SOARES, MRM; MIAMOTO, A; LOPES, APM; DIASARIEIRA, CR. 2018. Supressão da penetração de Meloidogyne javanica em tomateiro por produtos alternativos. In: CONGRESSO BRASILEIRO DE NEMATOLOGIA, 35. Anais... Bento Gonçalves, SBN, s/n.

COSTA, JCB; RESENDE, MLV; RIBEIRO JÚNIOR, PM; CAMILO, FR; MONTEIRO, ACA; PEREIRA, RB. 2010. Indução de resistência em mudas de cacaueiro contra Moniliophthora perniciosa por produto à base de mananoligossacarídeo fosforilado. Tropical Plant Pathology 35: 285-294.

COUTO, EAA; DIAS-ARIEIRA, CR; KATH, J; HOMIAK, JA; PUERARI, HH. 2016. Boron and zinc inhibit embryonic development, hatching and reproduction of Meloidogyne incognita. Acta Agriculturae Scandinavica, Section B - Soil \& Plant Science 66: 346-352.

DIAS-ARIEIRA，CR; CUNHA，TPL; CHIAMOLERA, FM; PUERARI, HH; BIELA, F; SANTANA, SM. 2012. Reaction of vegetables and aromatic plants to Meloidogyne javanica and $M$. incognita. Horticultura Brasileira 30: 322-326.
DŁUŻNIEWSKA, J. 2008. The effect of foliar fertilizers on the development and activity of Trichoderma spp. Polish Journal of Environment Studies 17: 869-874.

FERREIRA, DF. 2011. Sisvar: a computer statistical analysis system. Ciência $e$ Agrotecnologia 35: 1039-1042.

GHEYSEN, G; FENOLL, C. 2002. Gene expression in nematode feeding sites. Annual Review of Phytopathology 40: 191-219.

GOMES, RSS; DEMARTELAERE, ACF; NASCIMENTO, LC; MACIEL, WO; WANDERLEY, DBNS. 2016. Bioatividade de indutores de resistência no manejo da antracnose da goiabeira (Psidium guajava L.). Summa Phytopathologica 42: 149-154.

GOUVEA, A; KUHN, OJ; MAZARO, SM; MIO, LLM; DESCHAMPS, C; BIASI, LA; FONSECA, VC. 2009. Controle de doenças foliares e de flores e qualidade pós-colheita do morangueiro tratado com Saccharomyces cerevisiae. Horticultura Brasileira 27: $527-$ 533.

GOVINDASAMY, K; SEVUGAPPERUMA, N; DEVI, A. 2017. A proteomic approach to identify Bacillus subtilis induced defense related proteins in noni challenged with Meloidogyne incognita. International Journal of Plant, Animal and Environmental Sciences 7: 109-116.

HOYOS-CARVAJAL, L; ORDUZ, S; BISSET, J. 2009. Growth stimulation in bean (Phaseolus vulgaris L.) by Trichoderma. Biological Control 51: 409-416.

HU, HJ; CHEN, YL; WANG, YF; TANG, YY; CHEN, SL; YAN, SZ. 2017. Endophytic Bacillus cereus effectively controls Meloidogyne incognita on tomato plants through rapid rhizosphere occupation and repellent action. Plant Disease 101: 448-455.

JUNQUEIRA, KP; FALEIRO, FG; UESUGI, CH; JUNQUEIRA, NTV; BELLON, G; SANTOS, EC; RAMOS, LN. 2011. Desempenho agronômico de maracujazeiros tratados com produtos alternativos e fertilizantes foliares. Revista Brasileira de Fruticultura 33: 40-47.

KABATA-PENDIAS, A. 2011. Trace elements in soils and plants. 4. ed. Boca Raton: CRC Press. 505p.

MARSCHNER, P. 2012. Mineral nutrition of higher plants. 3. ed. London: Academic Press. 651p.

MIAMOTO, A; SILVA, MTR; DIAS-ARIEIRA, CR; PUERARI, HH. 2017. Alternative products for Pratylenchus brachyurus and Meloidogyne javanica management in soya bean plants. Journal of Phytopathology 165: 635-640.

OLIVEIRA, DF; SANTOS JÚNIOR, HM; NUNES, AS; CAMPOS, VP; PINHO, RSD; GAJO, GC. 2014. Purification and identification of metabolites produced by Bacillus cereus and B. subtilis active against Meloidogyne exigua, and their in silico interaction with a putative phosphoribosyl transferase from $M$. incognita. Anais $d a$ Academia Brasileira de Ciências 86: 525-538.

OLIVEIRA, MKRS; CHAVES, A; VIEIRA, DAN; SILVA, EJ; RODRIGUES, WDL. 2011. Controle biológico de fitonematóides 
do gênero Pratylenchus através de inoculante natural em cana-de-açúcar. Revista Brasileira Ciências Agrárias 6: 203-207.

PINHEIRO, JB. 2017. Nematoides em hortaliças. 1. ed. Brasília-DF: Embrapa. 194p.

RODRIGUES, VWB; BUENO, TV; TEBALDI, ND. 2016. Biofertilizantes no controle da mancha bacteriana (Xanthomonas spp.) do tomateiro. Summa Phytopathologica 42: 94-96.

R U M I A N I, M ; K A R E G A R , A ; HAMZEHZARGHANI, H; BANIHASHEMI, Z. 2016. Effect of elemental sulfur on the root-knot nematode, Meloidogyne incognita, activities in cucumber plants. Iranian Journal of Plant Pathology 52: 85-98.
SEDIYAMA, MAN; MAGALHÃES, IPB; VIDIGAL, SM; PINTO, CLO; CARDOSO, DSCP; FONSECA, MCM; CARVALHO, IPL. 2016. Uso de fertilizantes orgânicos no cultivo de alface americana (Lactuca sativa L.) 'Kaiser'. Revista Brasileira de Agropecuária Sustentável 6: 66-74.

SHARON, E; CHET, I; SPIEGEL, Y. 2011. Biological control of plant-parasitic nematodes: Trichoderma as a biological control agent. Biological Control 11: 183-201.

YU, Z; XIONG, J; ZHOU, Q; LUO, H; XIA, L; SUN, M; LI, L; YU, Z. 2015. The diverse nematicidal properties and biocontrol efficacy of Bacillus thuringiensis Cry6A against the root-knot nematode Meloidogyne hapla.
Journal of Invertebrate Pathology 125: 73-80. ZHANG, S; GAN, U; XU, B. 2015. Biocontrol potential of a native species of Trichoderma longibrachiatum against Meloidogyne incognita. Applied Soil Ecology 94: 21-29.

ZHANG, N; WANG, D; LIU, Y; LI, S; SHEN, Q; ZHANG, R. 2014. Effects of different plant root exudates and their organic acid components on chemotaxis, biofilm formation and colonization by beneficial rhizosphereassociated bacterial strains. Plant and Soil 374:689-700.

ZHENG, Z; ZHENG, J; ZHANG, Z; PENG, D; SUN, M. 2016. Nematicidal spore-forming Bacilli share similar virulence factors and mechanisms. Scientific Reports 6: 1-9. 